\title{
EFFECT OF TEMPORAL LAND USE/LAND COVER CHANGES ON ECOSYSTEM SERVICES VALUE IN COASTAL AREA OF CHINA: THE CASE OF SU-XI-CHANG REGION
}

\author{
YIRSAW, E. ${ }^{1}-$ WU, W. $.^{1,2^{*}}-$ TEMESGEN, H. ${ }^{1,3}-$ BEKELE, B. ${ }^{1,4}$ \\ ${ }^{I}$ Nanjing Agricultural University, College of Land Management, Nanjing 210095, China \\ (e-mail:eshetu.yirsaw@yahoo.com) \\ ${ }^{2}$ National and Joint Local Engineering, Research Center for Rural Land Resources Use and \\ Consolidation, Nanjing 210095, China \\ (e-mail:ww@njau.edu.cn) \\ ${ }^{3}$ Dilla University, Department of Land Resources Management, Dilla, Ethiopia \\ (e-mail:habte023@yahoo.com) \\ ${ }^{4}$ Assosa ATVET Collage, Department of Natural Resources Management, Assosa, Ethiopia \\ (e-mail:belewbekele@yahoo.com) \\ *Corresponding author \\ e-mail:ww@njau.edu.cn
}

(Received $30^{\text {th }}$ Jan 2016; accepted $28^{\text {th }}$ Apr 2016)

\begin{abstract}
Providing goods and services, while maintaining ecosystem service functions and biodiversity that built up their sustainable supply to support human welfare, is one of the great challenges of our time. This study examined the dynamics of land use land cover (LULC) changes, temporal variation of ecosystem service value (ESV), the threatened ecosystem services function in Su-Xi-Chang region, and explore the consequences of unsustainable use of land resources on ESV provision. Remote sensing applications were used to evaluate changes in LULC, and an evaluation method for ESV based on land cover change was applied in 2000, 2005 and 2010. Our study investigated that change in ESV was caused mainly due to the expansion of construction land, which was increased by $88 \%$ during the study period. Meanwhile, ESV dropped from $57.1775 \times 10^{9} \mathrm{CNY}$ in 2000 to $53.7585 \times 10^{9} \mathrm{CNY}$ in 2010. Ecosystem service function for food provision was the most critically affected followed by climate and gas regulation functions respectively. Waste treatment and water supply were the two largest services functions provided by ecosystems of the area. The expansion of construction land, which have due impact on LULC change, is likely responsible for the overall decline in 3.4190 billion CNY ESV of the region. As they have showed the highest ESV and greatest degradation during the study period, protection of farmland and water bodies should be paid due attention by regional land use planning and policy making offices. As a result, sustainable use of land resources and mitigation of the declining ESV of the region will be realized.
\end{abstract}

Keywords: land use land cover changes, ecosystem service value, sustainability, Su-Xi-Chang region

\section{Introduction}

Much importance is attributed to the search of knowledge about anthropogenic impact on our environment as rapid population growth and economic development intensify the stress that human beings place on the biosphere and ecosystems (Omenn, 2006; Long et al., 2009). Under land change science, an interdisciplinary fields seeks to understand the dynamics of LULC as a coupled human environment system to address theory, concepts, models, and applications relevant to environmental and social problems, has emerged as a fundamental component of global environmental change 
and sustainability research (De-yong et al., 2005; Secretariat, 2005; Turner et al., 2007; Tong et al., 2012; Estoque and Murayama, 2013).

Recently, issues related to LULC change have attracted interest among a wide variety of research, ranging from those who favor modeling spatio-temporal patterns of land conversion to those who try to understand the coupled system causes, impacts, and consequences (Irwin and Geoghegan, 2001; Xie et al., 2003; Long et al., 2009; Polasky et al., 2011; Mendoza-González et al., 2012; Ruishan and Suocheng, 2013; Wu et al., 2013; Long et al., 2014; Han et al., 2015; Ye et al., 2015). These are particularly becoming a hot issue in rapidly urbanizing areas. In connection to rapid socioeconomic development and population growth ( $\mathrm{Li}$ et al., 2010b; Su et al., 2012) in rapidly urbanizing areas, such as eastern coastal areas of China, the physical and ecological environments have been interrupted by intensive human-transformed land use system. These lead to deterioration and loss of natural and semi-natural environments and their associated ecosystem services value (Li et al., 2010b; Helian et al., 2011).

Since China initiated economic reforms and an open-door policy in 1978, tremendous change in China's development philosophy and regional economics have occurred (Wei and Fan, 2000). As a result, many coastal regions of China such as the Yangtez River Delta region and Pearl River Delta region experienced dramatic economic and spatial restructuring, which resulted in tremendous land use change (Seto and Kaufmann, 2003; Li and Yeh, 2004; Long et al., 2007). Empirical investigations in the coastal areas of China (Long et al., 2009; Liu et al., 2010) have shown that with the continuous growth of China's economy, massive farmland loss for the benefit of market farming and nonagricultural development occur without appropriate planning and management of existing land resources. This is affecting (Seto and Kaufmann, 2003; Liu et al., 2010; Liu et al., 2015) the natural and semi-natural environment and functions of ecosystem of the area, which have been in turn adversely affecting the living condition of the societies. Therefore, in these areas the research of change of ecosystem services under the background of LULC change is very important for the realization of sustainable use of land resources and coordinated development of the economy and environment.

Many studies have been through to consider the dynamics of LULC and its impact on ecosystem services (Guo et al., 2001; Poschlod et al., 2005; Wu et al., 2006; Dewan and Yamaguchi, 2009; Li et al., 2010b; Tianhong et al., 2010; Polasky et al., 2011; Estoque and Murayama, 2012; Long et al., 2014; Ye et al., 2015). Yet, in coastal areas of China, an overall monitoring and assessment of the change in the ecosystem service value, which could provide the needed base line information, is still lacking (Long et al., 2009). Hence, the goal of this study is to contribute to this endeavor by examining the effect of LULC change on the ESVs of these areas.

As one of the main Coastal area of China (Long et al., 2009; Zhou et al., 2014) the characteristics of LULC change in Su-Xi-Chang region is typical and representative as a result of its faster economic and population growth. Thus (Liu et al., 2010) it's a paramount important to assess the effect of dynamics in LULC changes on ESV of this area to attain sustainable ecosystem management and support regional sustainable development policies. In the present study we proposed to analyze change in LULC, and estimate the annual economic value of services provided by the ecosystems of Su-Xi-Chang region and determine its past and current status. The objectives of the study are to: (1) describe the temporal change characteristics of LULC in Su-Xi-Chang region; (2) scrutinize the change in ESV in relation to LULC changes during the study period; (3) explore the most critically affected ecosystem services function in the study area. 


\section{Materials and Methods}

\section{Study area}

Su-Xi-Chang region refers to three municipalities Suzhou, Wuxi, and Changzhou situated in the Southern Jiangsu Province, lies in the middle of Yangtze River Delta Economic zone of east China $\left(36^{0} 46^{\prime}-32^{\circ} 04^{\prime} \mathrm{N}, 119^{0} 08^{\prime}-121^{0} 15^{\prime} \mathrm{E}\right)$. It covers a total area of $17,500 \mathrm{~km}^{2}$ with an average elevation below 50 meters (Figure 1). The area has monsoon climate with an annual average temperature and precipitation of $15.3^{\circ} \mathrm{C}$ and $1,092 \mathrm{~mm}$ respectively.
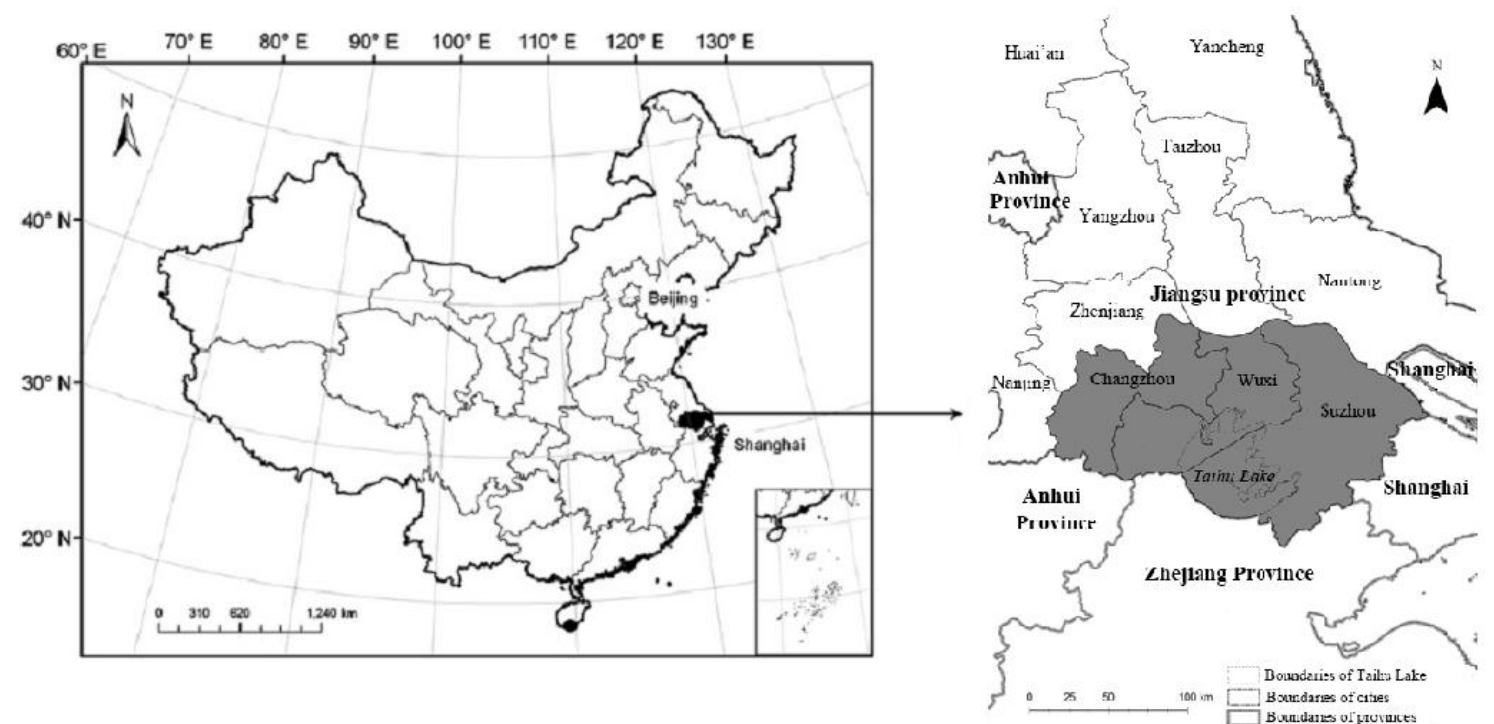

Figure 1. Location of the study area (gray colour)

Su-Xi-Chang has a total population of 14.65 million $\left(837 / \mathrm{km}^{2}\right)$, which was more than 6 times of the total population per $\mathrm{km}^{2}\left(135.5 / \mathrm{km}^{2}\right)$ of China in the same year. It is the most densely populated area in the country. The GDP per capita amounted to 123,325 CNY was about three times more than the GDP per capita of China at the same period (NBSC, 2014). However, with the growth of population and economic activities, LULC in $\mathrm{Su}-\mathrm{Xi}$-Chang region has changed dramatically as evidenced by the continuous decline of farmland (Long et al., 2007). And also due to loss and neglected protection of the environment the consequences of uncontrolled rural industrialization in this region are particularly serious (Xie et al., 2007). Furthermore (Zhou et al., 2014), rapid change of LULC and the ongoing deterioration of local environment are major concerns in SuXi-Chang region, which are triggering significant environmental consequences and causes loss in ESV of the region. These make it an appropriate case study to assess the effect of changes in LULC on ESV of the area to attain sustainable ecosystem service management and provide basic human welfare.

\section{LULC changes detection}

The data used in this study included land use maps of 2000, 2005 and 2010, derived from Landsat TM images and DEM data (resolution $30 \mathrm{~m}$ ) of the Computer Net Work 
Information Center, Chinese Academy of Science, and vector data of administrative boundaries at county level, provided by the Data Sharing Infrastructure of Earth system Science, Institute of Geographic Sciences and Natural Resources Research, Chinese Academy of science. The land use types were classified in to six categories: farmland, woodland, grassland, water body, wetland and construction land (Table 2).

\section{Model of LULC change}

The quantity change of land cover can be represented by the single land cover dynamic index, which denotes the change rate of a certain land cover type for a specific period of time. By analyzing the dynamic of land cover, the extent and rate of land cover change can be compared quantitatively (Yuhai, 1999) (Eq. 1).

$$
\mathrm{K}=\frac{\mathrm{U}_{\mathrm{b}}-\mathrm{U}_{\mathrm{a}}}{\mathrm{U}_{\mathrm{a}}} \times \frac{1}{\mathrm{~T}} \times 100 \%
$$

where $K$ is the single land cover dynamic index; $U_{\mathrm{a}}$ and $U_{\mathrm{b}}$ are the areas of a certain land cover class at time $a$ and time $b$ respectively; $T$ is the time span from time $a$ to time $b$. When $T$ is in a unit of year, then $K$ is the annual rate of change in area for this land cover type. $K$ ranges from -1 to $1 . K<0$ means that land cover type is in a state of depletion. The larger the absolute value of $K$, the more intensively land has been depleted. $K \geqslant 0$ means just the opposite.

\section{Assessment of ecosystem service values (ESVs)}

In order to estimate the global ecosystem services value (Costanza et al., 1997) classified the global biosphere into 16 ecosystem types and 17 service functions. Based on Costanza et al. (1997) parameters, (Xie et al., 2003) extracted the equivalent weight factor of ecosystem service per hectare of terrestrial ecosystems in China and modified the value coefficient of Chinese ecosystem. This equivalent weight factor (Table 1) can be applied to different regions across China by localizing the average natural food production (Xie et al., 2003). Equivalent weight factors are the potentials of ecosystems to provide ecosystem services. One factor is equal to the economic value of average grain production of crop land per hector per year. Generally, the natural food production is proposed to be 1/7 of the actual food production (Li et al., 2010a; Liu et al., 2012). With Su-Xi-Chang region, the average actual food production of crop was $6,765.33 \mathrm{~kg} / \mathrm{ha}$ from $2000-2010$ and the average price for grain was $1.86 \mathrm{CNY} / \mathrm{kg}$ in 2010 (NBSC, 2014). Therefore the ESV of one equivalent weight factor for $\mathrm{Su}-\mathrm{Xi}$ Chang region is $1,797.65 \mathrm{CNY} \mathrm{ha}^{-1}$.

Table 1. Equivalent weighting of ecosystem services per hectare of terrestrial ecosystems in China $^{a}$

\begin{tabular}{lllllll}
\hline & Farmland & Forest & Grassland & Wetland & $\begin{array}{l}\text { Water } \\
\text { body }\end{array}$ & $\begin{array}{l}\text { Barren } \\
\text { land }\end{array}$ \\
\hline Gas regulation & 0.50 & 3.50 & 0.80 & 1.80 & 0 & 0 \\
Climate regulation & 0.89 & 2.70 & 0.90 & 17.10 & 0.46 & 0 \\
Water supply & 0.60 & 3.20 & 0.80 & 15.50 & 20.40 & 0.03 \\
\hline
\end{tabular}




\begin{tabular}{|c|c|c|c|c|c|c|}
\hline $\begin{array}{l}\text { Soil formation and } \\
\text { protection }\end{array}$ & 1.46 & 3.90 & 1.95 & 1.71 & 0.01 & 0.02 \\
\hline Waste treatment & 1.64 & 1.31 & 1.31 & 18.18 & 18.20 & 0.01 \\
\hline $\begin{array}{l}\text { Biodiversity } \\
\text { protection }\end{array}$ & 0.71 & 3.26 & 1.09 & 2.50 & 2.49 & 0.34 \\
\hline Food production & 1.00 & 0.10 & 0.30 & 0.30 & 0.10 & 0.01 \\
\hline Raw material & 0.01 & 2.60 & 0.05 & 0.07 & 0.01 & 0 \\
\hline $\begin{array}{l}\text { Recreation and } \\
\text { culture }\end{array}$ & 6.91 & 1.28 & 0.04 & 5.55 & 4.34 & 0.01 \\
\hline Total & 6.91 & 21.85 & 7.24 & 62.71 & 46.01 & 0.42 \\
\hline
\end{tabular}

${ }^{\mathrm{a}}$ From Xie et al. (2003).

To obtain the ecosystem services value per unit area for each land use category in Su-Xi-Chang region, each category was compared with the nearest equivalent ecosystem suggested by Xie et al. For example, woodland equates to forestland, and construction land equates to barren land. Although the biome used as proxies for the land use categories are clearly not perfect matches in every case (Kreuter et al., 2001), they are closely related. Estimation of the ESV based on land use data has been applied and has been proven to be feasible in other case studies (Li et al., 2010b; Liu et al., 2012; Wu et al., 2013; Tang et al., 2014).

\section{Estimation of ESVs}

Once the ESVs of one unit area for each land use category has been extracted, the total value of ecosystem services in the study area from 2000 to 2010 was obtained as follows (Li et al., 2010a; Liu et al., 2012):

$$
\mathrm{ESV}=\sum\left(\mathrm{A}_{\mathrm{k}} \times \mathrm{VC}_{\mathrm{k}}\right)
$$

where $E S V$ is the ecosystem service value, $A_{k}$ is the area (ha) and $V C_{k}$ is the value coefficient (CNY ha ${ }^{-1} \mathrm{yr}^{-1}$ ) for land use category " $k$ ".

In addition, we also estimated the impacts of LULC change on nine individual ecosystem functions. The values of services provided by individual ecosystem functions were calculated using the following equation (Li et al., 2010a; Liu et al., 2012):

$$
\mathrm{ESV}_{\mathrm{f}}=\sum\left(\mathrm{A}_{\mathrm{k}} \times \mathrm{VC}_{\mathrm{fk}}\right)
$$

were $E S V_{f}$ is the estimated ESV of the function category " $f$ ", $A_{k}$ is the area (ha) and $V C_{f k}$ is the value coefficient $\left(\mathrm{CNY} \mathrm{ha}^{-1} \mathrm{yr}^{-1}\right)$ for land use category " $k$ ".

Since the biomes we used as proxies for the land use categories are not perfect matches as mentioned above, and there are uncertainties of the value coefficients, additional sensitivity analysis was used to check the percentage change in ESV for a given percentage change in a value coefficients. For each analysis, we calculated a 
coefficient of sensitivity (CS) using the standard economics concept of elasticity, as follows (Kreuter et al., 2001; Wang et al., 2015):

$$
\mathrm{CS}=\frac{\left(\mathrm{ESV}_{\mathrm{j}}-\mathrm{ESV}_{\mathrm{i}}\right) / \mathrm{ESV}_{\mathrm{i}}}{\left(\mathrm{VC}_{\mathrm{ik}}-\mathrm{VC}_{\mathrm{ik}}\right) / \mathrm{VC}_{\mathrm{ik}}}
$$

were $V C$ is the value coefficient, $E S V$ is the estimated ecosystem service value, and i and $\mathrm{j}$ represent the initial and adjusted values, respectively. If $C S>1$, then the estimated ecosystem value is elastic with respect to that coefficient and it is important to accurately define $V C$; but if $V C<1$, then the estimated ecosystem value is considered to be inelastic and the results of ESV calculation will be reliable even if the $V C$ value has relatively low accuracy.

In addition to monitoring the change in ESVs of Su-Xi-Chang region, a human-toecosystem service value (H-ESV) ratio index was also determined to assess the relationship between human population and the ESV. This was done by dividing the total ESV of Su-Xi-Chang region at a given period (e.g. 2000) by the population of the region during the said period.

\section{Results}

\section{LULC change characteristics}

Table 2 summarized the overall change trend of different LULC types over the study period. During this period, areas of woodland, grassland, and construction land increased, while that of farmland, water body and wetland decreased. In 2010, farmland was still the largest land cover category, followed by construction land and water body. Over the past one decade, the construction land has grown by 227,536 ha. In contrast, farm land has decreased by 216,352 ha, followed by water body and wet land, which decreased by 14,254 ha and 218 ha respectively. The expansion of construction land through the study period was caused mainly by the decrease of farmland and water body. Even though it kept an accelerating rate of decrease through the study period as compared to other land uses, farmland was the largest land use types in the study area.

Table 2. Su-Xi-Chang region land use patterns in 2000, 2005, and 2010

\begin{tabular}{lllllll}
\hline & \multicolumn{2}{c}{2000} & \multicolumn{2}{c}{2005} & \multicolumn{2}{c}{2010} \\
\cline { 2 - 7 } Land use type & Area (ha) & $\%$ & Area (ha) & $\%$ & Area (ha) & $\%$ \\
\hline Woodland & 117,154 & 6.72 & 118,656 & 6.80 & 119,831 & 6.87 \\
Grassland & 1,592 & 0.09 & 1,875 & 0.11 & 2,203 & 0.13 \\
Farmland & 864,338 & 49.54 & 776,408 & 44.50 & 647,986 & 37.14 \\
Wetland & 3,672 & 0.21 & 5,306 & 0.30 & 3,454 & 0.20 \\
Water body & 499,309 & 28.62 & 489,299 & 28.05 & 485,055 & 27.80 \\
Construction land & 258,559 & 14.82 & 353,080 & 20.24 & 486,095 & 27.86 \\
Total & $1,744,624$ & 100 & 174,4624 & 100 & $1,744,624$ & 100 \\
\hline
\end{tabular}

The quantity change of land cover illustrated by the single land cover dynamic index $(K)$ was greatest for construction land, followed by grass land. This indicates that the 
change rate of construction and grass lands were higher as compared to other. On the contrary, $K$ was smallest for farmland, followed by wetland and water body. In the other way the absolute value of farmland was greater than the values of wetland and water body. This illustrates that farmland was the most reduced land use type in the study region. Overall, farmland, construction land and water body were the primary land cover types in the study area, contributed to about $93 \%$ of the total land cover.

\section{Change in ESVs}

The ESVs for each land use category and the total value for each study year (2000, 2005, and 2010) were calculated using modified value coefficient and the area covered by each land use category (Table 3). The total ESV for Su-Xi-Chang region gradually decreased over the study period. The results revealed a decrease of around 3.42 billion CNY worth of ESV from 2000 to 2010 (Table 4). Of the total decrease by 6\%, for the past 10 years, about $61 \%$ was due to lose of farmland. Although the ESVs of forest and grasslands increased, the increases were too small to compensate the declines.

Table 3. ESVs (CNY ha $\left.\mathrm{hr}^{-1}\right)$ of different land use types in Su-Xi-Chang region

\begin{tabular}{|c|c|c|c|c|c|c|}
\hline & $\begin{array}{l}\text { Wood } \\
\text { land }\end{array}$ & $\begin{array}{l}\text { Grass } \\
\text { land }\end{array}$ & $\begin{array}{l}\text { Farm } \\
\text { land }\end{array}$ & Wetland & $\begin{array}{l}\text { Water } \\
\text { body }\end{array}$ & $\begin{array}{l}\text { Construct } \\
\text {-ion land }\end{array}$ \\
\hline Gas regulation & 6291.5 & 1438.1 & 898.8 & 32335.6 & 0.00 & 0.00 \\
\hline $\begin{array}{l}\text { Climate } \\
\text { regulation }\end{array}$ & 4853.5 & 1617.8 & 1599.8 & 30738.6 & 826.9 & 0.00 \\
\hline Water supply & 5752.3 & 1438.1 & 1078.6 & 27862.5 & 36670.6 & 53.9 \\
\hline $\begin{array}{l}\text { Soil formation } \\
\text { and retention }\end{array}$ & 7010.6 & 3505.3 & 2624.5 & 3073.9 & 18.0 & 36.0 \\
\hline Waste treatment & 2354.8 & 2354.8 & 2948.0 & 32680.0 & 32716.0 & 18.0 \\
\hline $\begin{array}{l}\text { Biodiversity } \\
\text { protection }\end{array}$ & 5860.1 & 1959.4 & 1276.3 & 4494.0 & 4476.0 & 611.2 \\
\hline Food & 179.8 & 539.3 & 1797.6 & 539.3 & 179.8 & 18.0 \\
\hline Row material & 4673.7 & 89.9 & 179.8 & 125.8 & 18.0 & 0.00 \\
\hline $\begin{array}{l}\text { Recreational and } \\
\text { culture }\end{array}$ & 2300.9 & 71.9 & 18.0 & 9976.6 & 7801.5 & 18 \\
\hline Total & 39277.2 & 13014.6 & 12421.4 & 141826.3 & 82706.8 & 755.1 \\
\hline
\end{tabular}

Because water body has the highest value coefficient (Table 1) and covers a larger area (Table 2), the ESV of water body was the highest of the six land use types, accounting for about $75 \%$ of the total values. Farmland also generates a high service value because of its large area. Water body combined with farmland and woodland accounted for over $98 \%$ of the total ESVs produced in the region. This indicated that, the three land use types play major roles in providing ecosystem services. Although the wetland value coefficient was the highest of all land uses (Table 1), wetland cover a small area in $\mathrm{Su}-\mathrm{Xi}$-Chang region, thus this land use was associated with a very low service value. The ESV for grassland is also low for the same reason. 
Table 4. Total ESV for each land use types in Su-Xi-Chang region in 2000, 2005, and 2010

\begin{tabular}{llllll}
\hline & \multicolumn{3}{c}{ ESV $\left(\times 10^{9} \mathrm{CNY} \mathrm{yr}^{-1}\right)$} & \multicolumn{2}{c}{ Change $(2000-2010)^{\mathrm{a}}$} \\
\cline { 2 - 6 } Land use type & 2000 & 2005 & 2010 & $\times 10^{9} \mathrm{CNY}$ & $\%$ \\
\hline Woodland & 4.6015 & 4.6605 & 4.7066 & 0.1051 & 2.2840 \\
Grassland & 0.0207 & 0.0244 & 0.0287 & 0.008 & 38.6473 \\
Farmland & 10.7363 & 9.6441 & 8.0489 & -2.6874 & -25.0310 \\
Wetland & 0.5208 & 0.7525 & 0.4899 & -0.0309 & -5.9332 \\
Water body & 41.2962 & 40.4684 & 40.1173 & -1.1789 & -2.8547 \\
Construction land & 0.1952 & 0.2666 & 0.3671 & 0.3651 & 187.0390 \\
Total & 57.1775 & 55.8165 & 53.7585 & -3.4190 & -5.9796 \\
\hline
\end{tabular}

${ }^{\mathrm{a}}$ Positive and negative values represent increases and decreases, respectively.

Table 5 presented overall trends in the ESV of ecosystem service function types for the study area from 2000 to 2010 . Waste treatment and water supply were the dominant ecosystem service function types. They accounted for about $70 \%$ of the total ESVs on average, and the relative importance of each category remained the same over the study period. However, it is obvious that the ESVs of all the ecosystem service functions decreased slowly but substantially over time. The substantial decline in total ESV in the study period may be attributed to a loss of natural and semi-natural land cover types, especially farmland and water body, due to an accelerated urban expansion.

Table 5. Values of ecosystem service functions (ESVf) for Su-Xi-Chang region in 2000, 2005, and 2010

\begin{tabular}{|c|c|c|c|c|c|c|}
\hline \multirow{2}{*}{$\begin{array}{l}\text { Ecosystem service } \\
\text { function }\end{array}$} & \multicolumn{2}{|l|}{2000} & \multicolumn{2}{|l|}{2005} & \multicolumn{2}{|l|}{2010} \\
\hline & $\begin{array}{l}\mathrm{ESV}_{\mathrm{f}}\left(\times 10^{9}\right. \\
\left.\mathrm{CNY} \mathrm{yr}^{-1}\right)\end{array}$ & $\%$ & 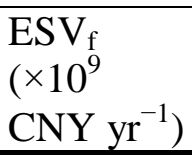 & $\%$ & $\begin{array}{l}\mathrm{ESV}_{\mathrm{f}}\left(\times 10^{9}\right. \\
\left.\mathrm{CNY} \mathrm{yr}^{-1}\right)\end{array}$ & $\%$ \\
\hline Gas regulation & 1.6350 & 2.85 & 1.6162 & 2.90 & 1.4512 & 2.70 \\
\hline $\begin{array}{l}\text { Climate } \\
\text { regulation }\end{array}$ & 2.4798 & 4.32 & 2.3887 & 4.28 & 2.1288 & 3.96 \\
\hline Water supply & 20.0347 & 34.93 & 19.6322 & 35.16 & 19.3011 & 35.90 \\
\hline $\begin{array}{l}\text { Soil formation } \\
\text { and retention }\end{array}$ & 3.1169 & 5.43 & 2.9140 & 5.22 & 2.5852 & 4.81 \\
\hline Waste treatment & 19.2878 & 33.63 & 18.7605 & 33.61 & 18.1885 & 33.83 \\
\hline $\begin{array}{l}\text { Biodiversity } \\
\text { protection }\end{array}$ & 4.2020 & 7.32 & 4.1287 & 7.40 & 4.0172 & 7.47 \\
\hline Food & 1.6722 & 2.92 & 1.5153 & 2.71 & 1.2854 & 2.39 \\
\hline Row material & 0.7125 & 1.24 & 0.7039 & 1.26 & 0.6859 & 1.28 \\
\hline $\begin{array}{l}\text { Recreational and } \\
\text { culture }\end{array}$ & 4.2219 & 7.36 & 4.1637 & 7.46 & 4.1151 & 7.66 \\
\hline Total & 57.3709 & 100 & 55.8232 & 100 & 53.7584 & 100 \\
\hline
\end{tabular}




\section{Variation of ESVs in response to LULC change and other factors}

Figure 2 showed a significant negative linear relationship between expansion of construction land and total ESVs. Construction land increased by a factor of $88 \%$, from 258,559 ha in 2000 to 486,095 ha in 2010. At the same time the total ESVs decreased by about 6\%, from 57.1775 billion CNY in 2000 to 53.7585 billion CNY in 2010. Furthermore, Figure 3 showed significant polynomial decline in ESV per capita to GDP per capita from 2000 to 2010. Herein, both Figure 2 and 3 indicate that both expansion of construction land and rapid economic growth has a substantial negative impact on the regional ecosystem services.

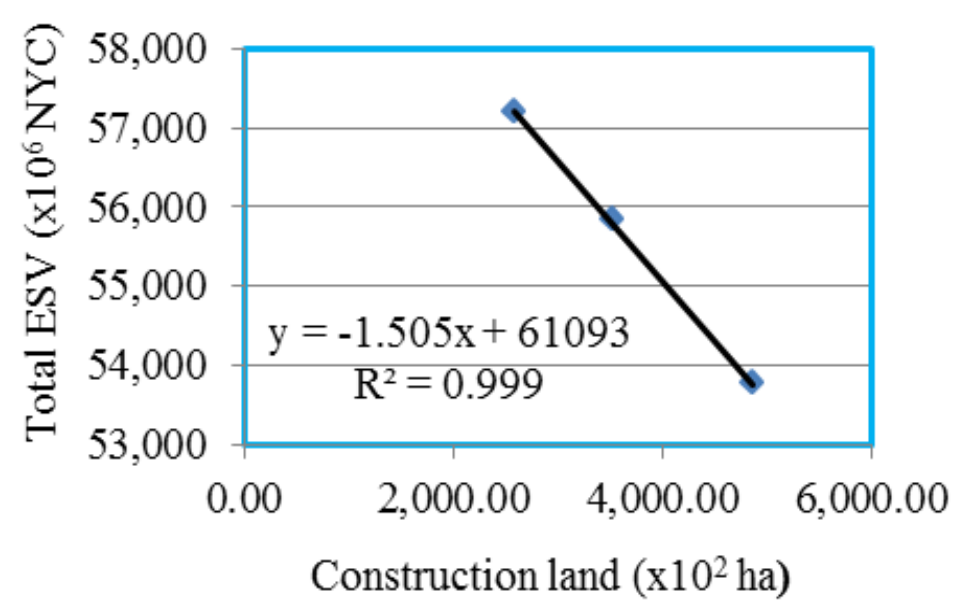

Figure 2. Relationship between ESV and construction land from 2000 to 2010

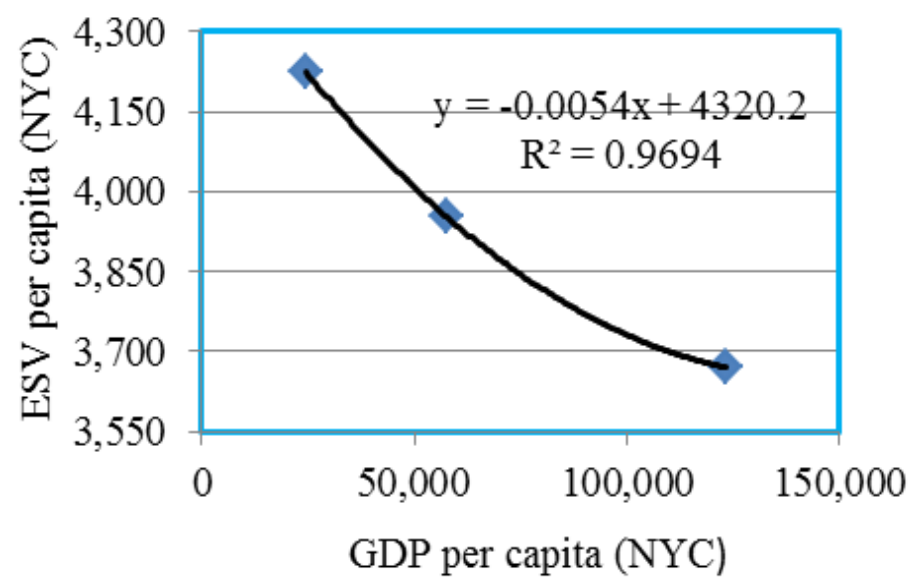

Figure 3. Relationship between ESV per capita and GDP per capita from 2000 to 2010

Similarly H-ESV ratio shows a declined trend. The H-ESV ratio in 2000 was about 1: 4,222 (CNY/year), but this has decreased to around 1: 3,953 and 1: 3,670 in 2005 and 2010, respectively. Showing that, the total benefits of human welfare to be obtained from the ecosystem services of the region were decreased by $13 \%$ during the study period. 


\section{Ecosystem sensitivity analysis}

For the results of our analysis to be reliable, the sensitivity of ESV to changes in the value coefficients must be relatively low $(C S<1)$. Using (Eq. 4$)$, the percentage change in the estimated total ESVs and the corresponding coefficient of sensitivity $(C S)$ resulting from a $50 \%$ adjustment in the value of the service value coefficient, indicated that the total ESVs estimated in this study was relatively inelastic with respect to change in the value coefficients (Table 6). CS was highest for water body (0.75) because of the large area and high value coefficient for this land use type. Overall, the sensitivity analysis indicated that all the results of $C S$ were less than 1, meaning the total value of ecosystem services is not sensitive to the change of $V C$, so the values of $V C$ were suitable and the results are credible despite uncertainty in the value coefficient.

Table 6. Percentage change in estimated total ESV and coefficient of sensitivity (CS) resulting from a $50 \%$ adjustment in ecosystem valuation coefficients (VC) in Su-Xi-Chang region

\begin{tabular}{lllll}
\hline Change in valuation & 2000 & & 2010 & \\
\cline { 2 - 5 } coefficient & $\%$ & CS & $\%$ & CS \\
\hline Woodland VC $\pm 50 \%$ & \pm 4.02 & 0.08 & \pm 4.37 & 0.09 \\
Grassland VC $\pm 50 \%$ & \pm 0.02 & 0.0003 & \pm 0.03 & 0.0005 \\
Farmland VC $\pm 50 \%$ & \pm 9.39 & 0.19 & \pm 7.49 & 0.15 \\
Wetland VC $\pm 50 \%$ & \pm 0.46 & 0.01 & \pm 0.46 & 0.01 \\
Water body VC $\pm 50 \%$ & \pm 36.11 & 0.72 & \pm 37.31 & 0.75 \\
\hline
\end{tabular}

\section{Discussion}

Given the ongoing trend of urbanization and socioeconomic development in the $\mathrm{Su}$ $\mathrm{Xi}$-Chang region an increasing demand for land will speed up LULC change. This change in LULC brought a significant impairment on ecological function that supports the human-dominated ecosystem. During the study period the total ESVs of Su-XiChang region was decreased by 3.4190 billion CNY, which was mainly caused by the decrease in values of farmland and water body. According to the land use conversion matrix, from 2000 to 2010, there was a substantial increase in construction land over the other land use types from 258,559 ha to 486,095 ha. Remarkably, this growth exceeded the amount of land converted from construction land to other land cover types.

From the single land cover dynamic index $(K)$ point of view in our study area, farmland, water body and wetland were under the state of depletion, with $K$ values $<0$. While construction land, woodland and grassland, with $K$ value $>0$, were under the state of development. The degree of change of construction land, with about $9 \%$ of $K$ value, was far greater than all other land use categories; showing that it was under fast state of dynamics of development. Its expansion was caused mainly by the decrease of farmland and water body, which have high ESV. Construction land showed significant negative linear relationship (Figure 2) with ESV of the region. Even if the ESVs of forest and grasslands improved through the study time, these rises were not adequate to counterbalance the decreases due to construction land expansion. Thus change in LULC, due to increase in construction land with lower ESV, is responsible for a remarkable decline in total ESV of the region. 
As proposed by (Costanza et al., 1997), and modified by (Xie et al., 2003) to account for Chinese conditions, the method we used to estimate ESV derives from multiplying ESV by the area of a given land use category by the corresponding value coefficient (Table 4). However, as discussed in (Daily, 1997; Limburg et al., 2002; Turnera et al., 2003; Hein et al., 2006; Liu et al., 2012), estimates produced using this method have low resolution, high variation, and high uncertainty due to the complex, dynamic, and nonlinear properties of ecosystems. In addition, the accuracy of the modified value coefficient (Table 1) is doubtful because of ecosystem heterogeneity.

Different studies used various valuation methods to calculate value coefficient (Koschke et al., 2012; Wu et al., 2013) of ESV. Although different valuation methods may lead to different estimated values, leading to criticism of the ecosystem service valuation approach, it is important to remember that accurately calculating coefficients is less critical for time series analyses than for cross-sectional analyses, because these coefficients tend to affect estimates of directional change less than they affect estimates of the magnitude of ecosystem values at specific points in time ( $\mathrm{Li}$ et al., 2010a; Tianhong et al., 2010; Liu et al., 2012).

Since changes in ESV over time were the focus of our study, the results are reliable, particularly in quantitative terms. In our analysis uncertainties and errors would be reduced or offset by calculating the ESV in 2000, 2005 and 2010 and analyzing changes across this time period. In addition, our sensitivity analysis indicated that the total ESV that we estimated for the study area were relatively inelastic with respect to the value coefficients, and that our estimates were robust despite uncertainties in the value coefficients.

During the study period Su-Xi-Chang region experienced rapid economic development, which often seems to conflict with ecological protection. The ESV change degree index showed an average depletion of $6 \%$ of total ESV through the study period. Although the ecological and economical characteristics and the techniques of evaluation varied, the estimated results in Su-Xi-Chang region and the other areas of China consistently showed that ecosystem services and functions tend to decline under current patterns of urban economic development (De-yong et al., 2005; Wu et al., 2006; Liu et al., 2012). From 2000 to 2010 both total ESV versus GDP and ESV per capita versus GDP per capita in $\mathrm{Su}-\mathrm{Xi}$-Chang region showed a negative relationship. Although the decline in ESV was relatively low as compared to economic growth, which was still worth attention because the decrease in total ESV, 3.42 billion CNY with an average annual decline of 0.342 billion CNY, was far greater than researches in some other areas of China (Wu et al., 2006; Li et al., 2010a; Helian et al., 2011; Liu et al., 2012; Tang et al., 2014).

In connection to socioeconomic development in the past decade of time there was a change in demographic pattern of Su-Xi-Chang region. The H-ESV ratio index showed a decrease of values of ecosystem services for human welfare by a rate of 1.3 each year. This was mainly due to the unbalance between growth in total population, which was increased by $8.2 \%$ of the base year, and less development of ecosystem services of the region. All these are a signal to regional planners that they must focus more on sustainable land management and ecological protection of the region due to its fragile ecological environment, so as to maintain its ESVs in the future. 


\section{Conclusion}

In this study, LULC changes and their effect on ESVs were analyzed in the Su-XiChang region from 2000 to 2010. The result showed that over the past one decade, the areal extent of construction land was increased by $88 \%$, mainly at the expense of farmland and water body. However, the total ESV was decreased from 57.1775 billion CNY in 2000 to 53.7585 billion CNY in 2010, with a temporal change rate of $6 \%$. Food provision was the most affected ecosystem service function, which was reduced almost by a quarter of its base year value, mainly due to significant loss in farm land. Waste treatment and water supply were the most two ecological functions of the region. Farmland and water body were the ecosystems whose surface reduced the most, and yet, they were the ecosystems with the highest estimated service values.

Overall, our investigation revealed that the expansion of construction land, which have due impact on LULC change has had a direct effect on ecosystem services and their non-market economic values. Therefore, in Su-Xi-Chang region a compromise between expansion in construction land and ecological protection must be reached. To accomplish this, the regional land use planning must emphasize the protection of farmland and water body, for the realization of sustainable use of land resources and coordinated development of the economy and environment. Furthermore, since the ESVs of the region has been decreasing in an accelerating rate it is advisable to conduct research on prediction and modeling of this change in order to discern its rate and extent of dynamics in the upcoming time, to sustain the ecosystem service provision.

Acknowledgement. The authors are thankful to National Nature Sciences Foundation of China (Fund No. 41571176) for financial support and encouragement in conducting the study. We are also grateful to anonymous reviewers for their helpful comments and suggestions on earlier drafts of this manuscript.

\section{REFERENCES}

[1] Costanza, R., dArge, R., deGroot, R., Farber, S., Grasso, M., Hannon, B., Limburg, K., Naeem, S., ONeill, R.V., Paruelo, J., Raskin, R.G., Sutton, P., vandenBelt, M. (1997): The value of the world's ecosystem services and natural capital. - Nature 387: 253-260.

[2] Daily, G. (1997): Nature's services: societal dependence on natural ecosystems. Island Press.

[3] De-yong, Y., Yao-zhong, P., Yan-yan, W., Xin, L., Jing, L., Zhong-hua, L. (2005): Valuation of ecosystem services for Huzhou City, Zhejiang Province from 2001 to 2003 by Remote Sensing data. - Journal of Forestry Research 16: 223-227.

[4] Dewan, A.M., Yamaguchi, Y. (2009): Land use and land cover change in Greater Dhaka, Bangladesh: Using remote sensing to promote sustainable urbanization. - Applied Geography 29: 390-401.

[5] Estoque, R.C., Murayama, Y. (2012): Examining the potential impact of land use/cover changes on the ecosystem services of Baguio city, the Philippines: a scenario-based analysis. - Applied Geography 35: 316-326.

[6] Estoque, R.C., Murayama, Y. (2013): Landscape pattern and ecosystem service value changes: implications for environmental sustainability planning for the rapidly urbanizing summer capital of the Philippines. - Landscape and Urban Planning 116: 60-72.

[7] Guo, Z., Xiao, X., Gan, Y., Zheng, Y. (2001): Ecosystem functions, services and their values-a case study in Xingshan County of China. - Ecological economics 38: 141-154.

[8] Han, H., Yang, C., Song, J. (2015): Scenario Simulation and the Prediction of Land Use and Land Cover Change in Beijing, China. - Sustainability 7: 4260-4279. 
[9] Hein, L., Van Koppen, K., De Groot, R.S., Van Ierland, E.C. (2006): Spatial scales, stakeholders and the valuation of ecosystem services. - Ecological economics 57: 209228.

[10] Helian, L., Shilong, W., Guanglei, J., Ling, Z. (2011): Changes in land use and ecosystem service values in Jinan, China. - Energy Procedia 5: 1109-1115.

[11] Irwin, E.G., Geoghegan, J. (2001): Theory, data, methods: developing spatially explicit economic models of land use change. - Agriculture, Ecosystems \& Environment 85: 7-24.

[12] Koschke, L., Fuerst, C., Frank, S., Makeschin, F. (2012): A multi-criteria approach for an integrated land-cover-based assessment of ecosystem services provision to support landscape planning. - Ecological Indicators 21: 54-66.

[13] Kreuter, U.P., Harris, H.G., Matlock, M.D., Lacey, R.E. (2001): Change in ecosystem service values in the San Antonio area, Texas. - Ecological economics 39: 333-346.

[14] Li, J., Wang, W., Hu, G., Wei, Z. (2010a): Changes in ecosystem service values in Zoige Plateau, China. - Agriculture, Ecosystems \& Environment 139: 766-770.

[15] Li, X., Yeh, A.G.-O. (2004): Analyzing spatial restructuring of land use patterns in a fast growing region using remote sensing and GIS. - Landscape and Urban Planning 69: 335354.

[16] Li, Y., Long, H., Liu, Y. (2010b): Industrial development and land use/cover change and their effects on local environment: a case study of Changshu in eastern coastal China. Frontiers of Environmental Science \& Engineering in China 4: 438-448.

[17] Limburg, K.E., O'Neill, R.V., Costanza, R., Farber, S. (2002): Complex systems and valuation. - Ecological economics 41: 409-420.

[18] Liu, X., Li, Z., Liao, C., Wang, Q., Zhu, A., Li, D., Li, Y., Tang, Z. (2015): The development of ecological impact assessment in China. - Environment international 85: 46-53.

[19] Liu, Y., Li, J., Zhang, H. (2012): An ecosystem service valuation of land use change in Taiyuan City, China. - Ecological Modelling 225: 127-132.

[20] Liu, Y., Wang, J., Long, H. (2010): Analysis of arable land loss and its impact on rural sustainability in Southern Jiangsu Province of China. - Journal of Environmental Management 91: 646-653.

[21] Long, H., Liu, Y., Hou, X., Li, T., Li, Y. (2014): Effects of land use transitions due to rapid urbanization on ecosystem services: Implications for urban planning in the new developing area of China. - Habitat International 44: 536-544.

[22] Long, H., Liu, Y., Wu, X., Dong, G. (2009): Spatio-temporal dynamic patterns of farmland and rural settlements in $\mathrm{Su}-\mathrm{Xi}-\mathrm{Chang}$ region: Implications for building a new countryside in coastal China. - Land Use Policy 26: 322-333.

[23] Long, H., Tang, G., Li, X., Heilig, G.K. (2007): Socio-economic driving forces of landuse change in Kunshan, the Yangtze River Delta economic area of China. - Journal of Environmental Management 83: 351-364.

[24] Mendoza-González, G., Martínez, M., Lithgow, D., Pérez-Maqueo, O., Simonin, P. (2012): Land use change and its effects on the value of ecosystem services along the coast of the Gulf of Mexico. - Ecological economics 82: 23-32.

[25] National Bureau of Statistics of China (NBSC) (2014): China statistical yearbook. - China Statistics Press, Beijing.

[26] Omenn, G.S. (2006): Grand challenges and great opportunities in science, technology, and public policy. - Science-New York then Washington- 314: 1696.

[27] Polasky, S., Nelson, E., Pennington, D., Johnson, K.A. (2011): The impact of land-use change on ecosystem services, biodiversity and returns to landowners: A case study in the State of Minnesota. - Environmental and Resource Economics 48: 219-242.

[28] Poschlod, P., Bakker, J., Kahmen, S. (2005): Changing land use and its impact on biodiversity. - Basic and Applied Ecology 6: 93-98.

[29] Ruishan, H., Suocheng, D. (2013): Land use dynamics and landscape patterns in Shanghai, Jiangsu and Zhejiang. - Journal of Resources and Ecology 4: 141-148. 
[30] Secretariat, I. (2005): GLP (2005) science plan and implementation strategy. - IGBP Report No 53.

[31] Seto, K.C., Kaufmann, R.K. (2003): Modeling the drivers of urban land use change in the Pearl River Delta, China: integrating remote sensing with socioeconomic data. - Land Economics 79: 106-121.

[32] Su, S., Xiao, R., Jiang, Z., Zhang, Y. (2012): Characterizing landscape pattern and ecosystem service value changes for urbanization impacts at an eco-regional scale. Applied Geography 34: 295-305.

[33] Tang, Z., Shi, C., Bi, K. (2014): Impacts of land cover change and socioeconomic development on ecosystem service values. - Environmental Engineering and Management Journal 13: 2697-2705.

[34] Tianhong, L., Wenkai, L., Zhenghan, Q. (2010): Variations in ecosystem service value in response to land use changes in Shenzhen. - Ecological economics 69: 1427-1435.

[35] Tong, S., Sun, Y., Yang, Y. (2012): Generating a future land use change scenario with a modified population-coupled Markov Cellular Automata model. - Journal of Environmental Informatics 19: 108-119.

[36] Turner, B.L., Lambin, E.F., Reenberg, A. (2007): The emergence of land change science for global environmental change and sustainability. - Proceedings of the National Academy of Sciences 104: 20666-20671.

[37] Turnera, R.K., Paavolaa, J., Coopera, P., Farberb, S., Jessamy, V., Georgiou, S. (2003): Valuing nature: lessons learned and future research directions. - Ecological economics 46.

[38] Wang, Z., Wang, Z., Zhang, B., Lu, C., Ren, C. (2015): Impact of land use/land cover changes on ecosystem services in the Nenjiang River Basin, Northeast China. Ecological Processes 4: 1-12.

[39] Wei, Y.D., Fan, C.C. (2000): Regional inequality in China: a case study of Jiangsu province. - The Professional Geographer 52: 455-469.

[40] Wu, H.-I., Wang, X.-L., Ning, L.-M., Lu, Y.-F. (2006): Effects of land use change on ecosystem services value:--A case study in Wuhan City. - Resources and Environment in the Yangtze Basin 15: 186-190.

[41] Wu, K.-y., Ye, X.-y., Qi, Z.-f., Zhang, H. (2013): Impacts of land use/land cover change and socioeconomic development on regional ecosystem services: The case of fastgrowing Hangzhou metropolitan area, China. - Cities 31: 276-284.

[42] Xie, G.-D., Lu, C.-X., Leng, Y.-F., Zheng, D., Li, S. (2003): Ecological assets valuation of the Tibetan Plateau. - Journal of natural resources 18: 189-196.

[43] Xie, Y., Batty, M., Zhao, K. (2007): Simulating emergent urban form using agent-based modeling: Desakota in the Suzhou-Wuxian region in China. - Annals of the Association of American Geographers 97: 477-495.

[44] Ye, Y., Zhang, J.e., Chen, L., Ouyang, Y., Parajuli, P. (2015): Dynamics of ecosystem service values in response to landscape pattern changes from 1995 to 2005 in Guangzhou, southern China. - Applied Ecology and Environmental Research 13: 21-36.

[45] Yuhai, W.X.B. (1999): Study on the methods of land use dynamic change research [j]. Progress in Geography 1.

[46] Zhou, X., Chen, L., Xiang, W. (2014): Quantitative analysis of the built-up area expansion in Su-Xi-Chang region, China. - The journal of applied ecology 25: 14221430. 